The New Continentalism 
This page intentionally left blank 


\section{The New Continentalism}

Energy and Twenty-First-Century

Eurasian Geopolitics

Kent E. Calder

Yale UNIVERsity PRESS

NEW HAVEN AND LONDON 
Published under the auspices of the Johns Hopkins University/SAIS Reischauer Center for East Asian Studies.

Illustrations by Bill Nelson and Yukie Yoshikawa.

Copyright (C) 2012 by Kent E. Calder. All rights reserved.

This book may not be reproduced, in whole or in part, including illustrations, in any form (beyond that copying permitted by Sections IO7 and Io8 of the U.S. Copyright Law and except by reviewers for the public press), without written permission from the publishers.

Yale University Press books may be purchased in quantity for educational, business, or promotional use. For information, please e-mail sales.press@yale.edu (U.S. office) or sales@yaleup.co.uk (U.K. office).

ISBN: 978-0-300-I7IO2-o (pbk.)

Library of Congress Control Number: 2011940944

A catalogue record for this book is available from the British Library.

This paper meets the requirements of ANSI/NISO Z39.48-1992 (Permanence of Paper).

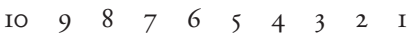


To the Memory of

Grant H. and Rose E. Calder

Who first showed me the nuance, and the beauty

Of the Silk Road 
"In Asia, the oldest inhabited continent, there has always been a strong, instinctive aversion to fixed boundaries."

—Lord George Curzon, "Frontiers"The 1907 Romanes Lecture, Oxford University

"Although the entire policy of a state does not derive from its geography, it cannot escape that geography. Size, shape, location, topography, and climate posit conditions from which there is no escape, however skilled the Foreign Office, and however resourceful the General Staff."

- Nicholas Spykman (1938) 